\author{
DEPARTMENT OF THE INTERIOR \\ UNITED STATES GEOLOGICAL SURVEY
}

\title{
AEROMAGNETIC MAP OF THE CARLSBAD AREA, NEW MEXICO AND TEXAS
}

\author{
GEOPHYSICAL INVESTIGATIONS \\ MAP GP-861
}

